\title{
Howard Brealey Carrington
}

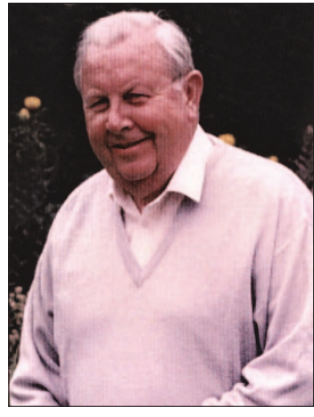

Born on 2 November 1921 in Kings Heath, Birmingham, Howard Carrington went to Moseley Grammar School and gained his Matriculation Exemption at the age of 15 . He should have been conscripted in 1942, but because of his Christadelphian upbringing, he became a conscientious objector. This forced him to work in the local agricultural centre.

At the end of 1943, Howard changed his religious thinking and enlisted in the army in 1944. The following four years saw him in army service in Palestine, Egypt, Syria, Lebanon and eventually in Cairo as a W.O. 1, where he was responsible for transport logistics. He was demobbed in 1947 and did a 'gap year' in Lewis's Store in Birmingham. From 1948 to 1953 he had a FETS grant to study dentistry at Birmingham University.

From January to July 1954 Howard was dental house surgeon at Edgeware General Hospital, London; he then became an associate of Ted Gee, Kings Norton until 1958. He enjoyed general dental practice in Solihull with a branch practice in Billesley from 19581988.

Howard served on the Representative Board and several local and national committees of the BDA from 1965 onwards, holding various positions including chairman, secretary and president of

\section{He will be remembered for his} forthrightness, humour, friendly association, generosity and as a champion of all general dental practitioners working within the NHS.

the Central Counties Branch. He was the first and only dental president of the Birmingham Medical Institute, and in 1989 was made a Life Member of the BDA. He received a silver salver from the Birmingham LDC in recognition of his service. He was also a zealous member of the Benevolent Fund Committee and administrator of the Sick Dentists' Scheme. A BDA man through and through, he retired from practice and politics in 1990.

Howard is survived by his wife Ann-Carol, three sons, one daughter and 10 grandchildren. He will be remembered for his forthrightness, humour, friendly association, generosity and as a champion of all general dental practitioners working within the NHS.

If you wish to remember Howard further, you can make an IN MEMORIAM gift to the BDA Benevolent Fund.

G.R. McColm

\section{Henry Noble}

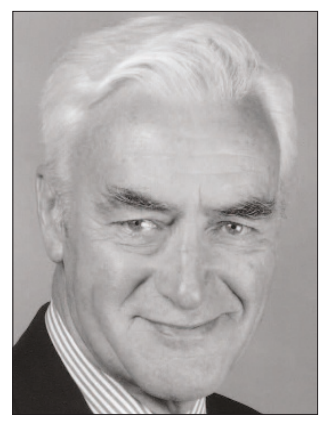

Like many others, Henry Noble was attracted to dentistry by the combination of academic study and fine manual work. A prize-winning student, he qualified from the University of Glasgow in 1947 and while a house surgeon became a demonstrator in dental histology - the field which was to become his life's work. He went on to serve Glasgow University as Lecturer and Senior Lecturer in histology and dental anatomy for 36 years. He also organised the College's Primary Fellowship exams, served as editor of the Glasgow Odontological Society and was elected as President in 1972 and later, an honorary member. The Glasgow Dental Alumnus association also benefited from his active support.

Henry championed basic science in dental education; an enthusiastic teacher, he was well known and loved by generations of students for his dramatic lecturing style and the lively group and practical sessions he led. From group microscopy through audio-visual techniques to computerised instruction, Henry was always eager to use the latest methods and was particularly proud of his students' elective achievements.

Though never a self-publicist or 'grant-grubber', Henry's laboratory was the technical nursery for numerous young researchers. In retirement he helped developing schools in Jordan and Trinidad and turned his meticulous scholarship to the history of dentistry. Under his energetic leadership the Glasgow

\section{Henry Noble was cast in a classical mould: a gentleman and a scholar, and we are all the poorer for his loss.}

History of Dental Research Group flourished, producing a biannual newsletter, historical articles and three theses. His contributions to the Lindsay Society and the BDA Museum were recognised in 2003 with the Tomes Medal. At a dinner given in his honour by the West of Scotland Branch - which pleased him enormously - he said 'Old Tomes was always a hero of mine'. Not long before his death he heard he was to receive the Lillian Lindsay Memorial Medal.

In his family life Henry showed the same qualities of boundless energy, unstinting enthusiasm and practical and kindly support - be it in boat building and sailing, in the home, the church or the local community. Henry and his wife Audrey celebrated their golden wedding with their four children and 10 grandchildren. He died in the Ayrshire Hospice on 10 October after an illness that cut short his travels this summer. There was a large attendance at his funeral service in Largs, beside the river Clyde which had been ever-present in his life.

Henry Noble was cast in a classical mould: a gentleman and a scholar, and we are all the poorer for his loss. 